\title{
Indomethacin Does Not Attenuate the Hypotensive Effect of Captopril, a Converting Enzyme Inhibitor in Goldblatt Hypertensive Rats
}

\author{
Ken Omata, Yoichi Otsuka, * Satoru Chiba, Toru Itoh, \\ Toshikazu Gotoh, Yutaka Imai, Yutaka Sakurai, Makito \\ Satoh, Toshiaki Haruyama, Masao Hiwatari, Ko Satoh, \\ Akira Kaitoh, Keishi Abe and Kaoru Yoshinaga
}

The Second Department of Internal Medicine, Tohoku University School of Medicine, Sendai 980

Omata, K., Otsuka, Y., Сhiba, S., ІтоH, T., Gotoh, T., Imai, Y., Sakurai, Y., Satoh, M., Haruyama, T., Hiwatari, M., Satoh, K., Кaitoh, A., Abe, K. and Yoshinaga, K. Indomethacin Does Not Attenuate the Hypotensive Effect of Captopril, a Converting Enzyme Inhibitor in Goldblatt Hypertensive Rats. Tohoku J. exp. Med., 1981, 134 (1), 9-19-Whether or not prostaglandins (PGs) have anything to do with the hypotensive effect of a converting enzyme inhibitor, captopril (SQ 14,225), was studied in two kidney one clip Goldblatt hypertensive rats. Four to 10 weeks after clipping the left renal artery of male Splague-Dawley rats, $50 \mathrm{mg} / \mathrm{kg}$ of captopril (Group 1, $n=7$ ) or $12.5 \mathrm{mg} / \mathrm{kg}$ of indomethacin (Group 2, $n=7$ ) were infused for $4 \mathrm{hr}$ under the conscious state. For the subsequent $4 \mathrm{hr}$, both $50 \mathrm{mg} / \mathrm{kg}$ of captopril and $12.5 \mathrm{mg} / \mathrm{kg}$ of indomethacin were infused in both groups of rats. Mean blood pressure (MBP) was recorded continuously. Plasma renin activity (PRA) and urinary excretion rate of PGE (UPGE) were measured by radioimmunoassay. Urinary sodium (UNa) and potassium (UK) excretions were measured by a flame photometer. After captopril infusion the pressor response to the injection of $100 \mathrm{ng}$ of angiotensin I decreased from $29.1 \pm$ 4.2 to $4.8 \pm 1.6 \mathrm{mmHg}$, and that of angiotensin II increased from $35.9 \pm 3.6$ to $75.0 \pm 5.1 \mathrm{mmHg}(p<0.01)$, while the response to norepinephrine did not change. Indomethacin did not affect these pressor responses. In the preinfusion period MBP, PRA or UPGE was not different significantly in the two groups of rats. The infusion of captopril decreased MBP from $202 \pm 11$ to $119 \pm 7.5 \mathrm{mmHg}(p<0.01)$ in the first group of rats. After the additional infusion of indomethacin MBP further decreased to $100 \pm 12 \mathrm{mmHg}$, depsite the significant decrease of UPGE from $915 \pm 34$ to $109 \pm 28 \mathrm{pg} / \mathrm{hr}(p<0.01)$, and PRA increased from $22.1 \pm 4.2$ to $34.1 \pm 7.1 \mathrm{ng} / \mathrm{ml} / \mathrm{hr}$. UNa did not change after captopril infusion but decreased significantly after indomethacin infusion from $49.0 \pm 5.0$ to $22.8 \pm 3.5 \mu \mathrm{Eq} / \mathrm{hr}$. In the second group captopril also decreased MBP from $187 \pm 7$ to $119 \pm 15 \mathrm{mmHg}$ ( $p$ $<0.01)$, and increased PRA from $24.1 \pm 6.1$ to $43.3 \pm 6.9 \mathrm{ng} / \mathrm{ml} / \mathrm{hr} \quad(p<0.01)$ despite the significant decrease of UPGE from $1219 \pm 294$ to $413 \pm 101 \mathrm{pg} / \mathrm{hr}$ by the pretreatment with indomethacin. UNa did not change in any period. The decrease of MBP was significantly correlated with the level of PRA prior to the infusion of captopril in both groups $(r=-0.69, p<0.01)$. UK did not change significantly in any period in the two groups of rats. Our data that indomethacin did not attenuate the hypotensive effect of captopril indicate that $\mathrm{PGs}$ do not

Received for publication, June 24, 1980.

* Dr. Y. Otsuka's present address: Izumigaoka Clinic, 2-1 Izumigaoka, Izumi 981-31. 
participate in the hypotensive effect of captopril and that the hypotensive effect of captopril is mainly due to the inhibition of renin-angiotensin system in two kidney one clip Goldblatt hypertensive rats. urinary prostaglandin E; plasma renin activity; captopril; indomethacin; Goldblatt hypertensive rat

An orally active angiotensin converting enzyme inhibitor, captopril (SQ14, 225), has been shown to lower the blood pressure of high renin type of hypertension by inhibiting the renin-angiotensin system in both animal models of hypertension and hypertensive human subjects. Since many investigators have demonstrated that captopril lowered also the blood pressure of low renin type of hypertension, the mechanism of blood pressure lowering effect of captopril may not be explained by the inhibition of the renin-angiotensin system alone. As Erdös and Yong (1970) have demonstrated that angiotensin converting enzyme and kininase II are the same protein, peptidyl dipeptide hydrolase, it is conceivable that the angiotensin converting enzyme inhibitor not only reduces the pressor activity of angiotensin I but also augments the vasodepressor activity of kinins. Recent studies have demonstrated that bradykinin releases prostaglandins from the kidney and blood vessels (McGiff et al. 1972) and prostaglandins potentiate the vasodilator effect of bradykinin (McGiff et al. 1972). Moreover, renal prostaglandins modulate the renal action of angiotensin (Aiken and Vane 1973), and mediate the renin release (Yun et al. 1976). Thus, it is postulated that prostaglandins may be involved in the mechanism of hypotensive effect of captopril.

To test this hypothesis, the hypotensive effect of captopril was compared in the presence and absence of prostaglandin synthesis inhibitor, indomethacin in two kidney one clip Goldblatt hypertensive rats.

\section{METHODS}

Male Splague-Dawley rats weighing 120-140 g were fed a standard rat chow (Oriental Yeast Co., Tokyo), containing $\mathbf{0 . 4 4} \%$ sodium chloride, and tap water ad libitum. All surgical procedures were done under ether anesthesia. Hypertension was induced by placing a U-shaped silver clip with an internal gap of $0.22 \mathrm{~mm}$ around the left renal artery. The contralateral kidney was left untouched. Systolic blood pressure was measured by a tail cuff method. Four to 10 weeks after the clipping, those rats having a systolic blood pressure of $160 \mathrm{mmHg}$ or higher at two consecutive measurements were placed in metabolic cages. Three days later, catheters were chronically implanted into the abdominal aorta and into the inferior vena cava through the femoral artery and vein. The catheters were threaded subcutaneously to the scapular region of rats. Two or three days after the vessel catheterization direct mean blood pressure (MBP) was measured by a pressure transducer (Narco, RP 1500) connected to the arterial catheter and recorded on a two channel recorder (SAN-EI, Type 1236). Only those rats having MBP of $140 \mathrm{mmHg}$ or above were used. During the experiment, the rats were not anesthetized and were free to move about in their metabolic cages, only partially restrained by a harness attached to springs on their backs. After the blood pressure was stabilized, the effects of angiotensin converting enzyme inhibitor, captopril (SQ 14,225), and indomethacin were studied in two groups of rats (7 rats in each group). In the first group, isotonic phosphate buffer $(0.01 \mathrm{M}, \mathrm{pH} 7.4)$ was infused through the venous catheter at $17.2 \mu \mathrm{l} / \mathrm{min}$ using a Harvard pump for $4 \mathrm{hr}$, then $50 \mathrm{mg} / \mathrm{kg}$ of captopril dissolved in the phosphate buffer were infused at $0.21 \mathrm{mg} / \mathrm{kg} / \mathrm{min}$ for $4 \mathrm{hr}$. For the subsequent $4 \mathrm{hr}$, both $50 \mathrm{mg} / \mathrm{kg}$ of captopril and $12.5 \mathrm{mg} / \mathrm{kg}$ of indomethacin dissolved 
in the phosphate buffer were infused at $0.21 \mathrm{mg} / \mathrm{kg} / \mathrm{min}$ and $0.05 \mathrm{mg} / \mathrm{kg} / \mathrm{min}$, respectively. In the second group, the same dose of indomethacin was infused after $4 \mathrm{hr}$ of control period, then both captopril and indomethacin were infused for $4 \mathrm{hr}$. MBP was recorded continuously and urine was collected in each period. Food was withheld during the experiment. Water was available ad libitum. At the end of each period, blood $(0.6 \mathrm{ml})$ was drawn from each rat for plasma renin activity (PRA) and hematocrit determinations. All blood samples were replaced immediately by injecting the same amount of blood obtained from donor rats which had been nephrectomized at least $2 \mathrm{hr}$ earlier. Rats with hematocrit of $40 \%$ or less at any time during the study were eliminated. After the blood sampling at the end of each period, $100 \mathrm{ng} / \mathrm{rat}$ of angiotensin I (1-Asp-5-Ile-Ang I, Protein Research Foundation, Osaka) and angiotensin II (Hypertensin, CIBA) and DL-norepinephrine (Sankyo, Tokyo) were administered separately as bolus injections through the venous catheter as previously described (Otsuka et al. 1979). Urinary sodium (UNa) and potassium (UK) were measured using a flame photometer. The hematocrit was determined by centrifuging the blood samples at $3,000 \mathrm{rpm}$ for $15 \mathrm{~min}$.

PRA was determined by a radioimmunoassay of modified Abe's method (Abe et al. 1972). Plasma, $0.25 \mathrm{ml}$, was incubated with sodium ethylendiamine tetraacetic acid (EDTA) and diisopropyl fluorophosphate (DFP) at $37^{\circ} \mathrm{C}$, pH 5.5 for $6 \mathrm{hr}$. After $2.25 \mathrm{ml}$ of saline were added, the samples were boiled for $15 \mathrm{~min}$. Then $10 \mu \mathrm{l}$ of samples were mixed with 6,000 $\mathrm{cpm}$ of angiotensin I and $100 \mu \mathrm{l}$ of dilute antiserum. One $\mathrm{ml}$ of Tris acetate buffer $0.2 \mathrm{M}$, pH 7.4 containing lysozyme $0.1 \%$ and EDTA $0.05 \%$ was added to the samples and the mixture was incubated at $4^{\circ} \mathrm{C}$ for $24 \mathrm{hr}$. The seperation of bound and free angiotensin $\mathrm{I}$ was done using dextran coated charcoal. PRA was expressed as ng of generated angiotensin $\mathrm{I} / \mathrm{ml}$ plasma/hr incubation.

Urinary excretion rate of prostaglandin E (UPGE) was measured radioimmunologically. One $\mathrm{ml}$ of urine sample was used for PGE determination. For the chemical conversion of PGE to PGB, $2 \mathrm{ml}$ of $1 \mathrm{~N} \mathrm{KOH}$ were added to each sample with shaking for $1 \mathrm{hr}$. Then the mixture was acidified with $1 \mathrm{~N} \mathrm{HCl}$ and extracted with $15 \mathrm{ml}$ of ethyl acetate. After the organic solution was dried, the residue was applied to a silicic acid column, and the PGB fraction was eluted with $4 \mathrm{ml}$ of a solvent (Abe et al. 1977). The separated PGB was radioimmunologically assayed using PGB antiserum. The PGB antisera were produced in our Laboratory according to Jaffe's method (Jaffe and Behrman 1974).

When comparing groups, statistical analysis was performed by Student's $t$ test, and all results were expressed as mean \pm s.E.M. The difference between mean values was considered to be significant when $p$ values were less than 0.05 .

\section{Results}

\section{$P G B$ radioimmunoassay}

Validation of $R I A$. The mean recovery of added tracer through the entire procedure was $65.6 \pm 0.5 \%$ (Chiba et al. in press).

Sensitivity. A $50 \%$ change in binding occurred at $48 \mathrm{pg}$ of $\mathrm{PGB}_{2}$. The binding in the presence of $6 \mathrm{pg}$ of $\mathrm{PGB}_{2}$ was always difierent from that in the absence of $\mathrm{PGB}_{2}$, and this was used as the lowest dose for the standard curve. An RIA standard curve for $\mathrm{PGB}_{2}$ is shown in Fig. 1. The titer of antiserum used was $\times 1600$.

Specificity. The antiserum showed a $4.3 \%$ affinity to $\operatorname{PGA}_{2}\left(\mathrm{~A}_{2}\right)$, and $0.3 \%$ affinity to $\mathrm{PGE}_{2}\left(\mathrm{E}_{2}\right), 0.03 \%$ to $\mathrm{PGF}_{2 \alpha}\left(\mathrm{F}_{2 \alpha}\right)$ and $0.01 \%$ to 15 keto $\mathrm{PGE}_{2}$. 13-14 dihydro 15 keto $\mathrm{PGE}_{2}, \mathrm{PGF}_{2 \alpha}$ MUM, or 6 keto $\mathrm{PGF}_{1 \alpha}$ was not cross reacted. But $\mathrm{PGB}_{1}$ cross reacted $100 \%$ (Fig. 1). 


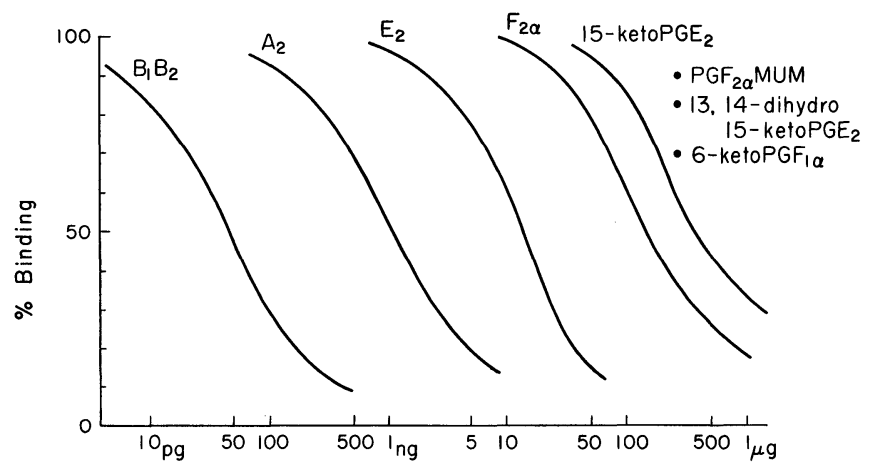

Fig. 1. A radioimmunoassay standard curve for $\mathrm{PGB}_{2}$ and cross reactions of various prostaglandins with an antiserum to $\mathrm{PGB}_{2}$. Abbreviations; $\mathrm{A}_{2}, \mathrm{PGA}_{2} ; \mathrm{B}_{1}, \mathrm{PGB}_{1} ; \mathrm{B}_{2}, \mathrm{PGB}_{2}$; $\mathrm{E}_{2}, \mathrm{PGE}_{2} ; \mathrm{F}_{2 \alpha}, \mathrm{PGF}_{2 \alpha}$.

\section{Pressor response to angiotensin I, II and norepinephrine}

Fig. 2 shows the pressor response to $100 \mathrm{ng}$ of angiotensin I (AI), angiotensin II (AII) and norepinephrine (NE) at the end of control period and the period in which both captopril and indomethacin were infused in 11 renal hypertensive rats. Since no difference in the pressor response to the pressor substances between the first group and the second was found, the results of these two groups were pooled. Since no difference was found between control period and indomethacin period in the second group, and between captopril period and captopril plus indomethacin period in the first group, the results were compared between control period and captopril plus indomethacin period. Captopril in a dose used in this study almost completely blocked the pressor response to AI from $29.1 \pm 4.2$ to $4.8 \pm 1.6 \mathrm{mmHg}$

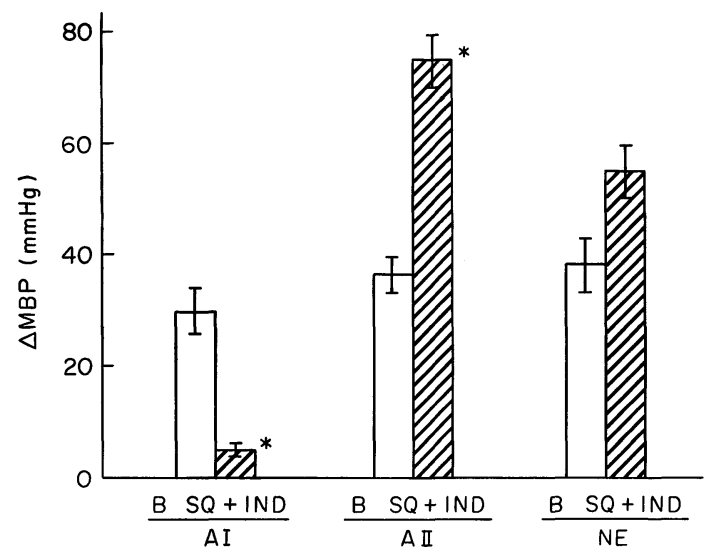

Fig. 2. The blood pressure response (MBP) to $100 \mathrm{ng}$ of angiotensin I (AI), angiotensin II (AII) and norepinephrine (NE) at the end of the control period (B, open bars) and the period in which both captopril and indomethacin (SQ+IND, hatched bars) were infused. Each value is the mean \pm s.E. for 11 renal hypertensive rats. *Significantly different $(p<0.01, n=11)$ from the response in the control period. 
and augmented the pressor response to AII from $35.9 \pm 3.6$ to $75.0 \pm 5.1 \mathrm{mmHg}$. The pressor response to $\mathrm{NE}$ increased from $39.3 \pm 4.7$ to $54.4 \pm 9.7 \mathrm{mmHg}$, but the difference was not statistically significant.

\section{Changes in $M B P, P R A$ and $U P G E$}

MBP, PRA and UPGE in the control period in each group are shown in Fig. 3. In the first group of renal hypertensive rats, $\mathrm{MBP}$ was $202 \pm 11 \mathrm{mmHg}, \mathrm{PRA}$ was $22.1 \pm 4.1 \mathrm{ng} / \mathrm{ml} / \mathrm{hr}$ and UPGE was $915 \pm 234 \mathrm{pg} / \mathrm{hr}$. In the second group of rats MBP was $206 \pm 8 \mathrm{mmHg}, \mathrm{PRA}$ was $24.1 \pm 6.1 \mathrm{ng} / \mathrm{ml} / \mathrm{hr}$ and UPGE was $1219 \pm 294$ $\mathrm{pg} / \mathrm{hr}$. Thus PRA was grossly elevated and MBP was extremely high in both groups. There were no significant differences between two groups in each parameter.

As shown in Fig. 4, the level of PRA ranged from 5 to $62 \mathrm{ng} / \mathrm{ml} / \mathrm{hr}$ and the value of UPGE varied widely between 169 and $2171 \mathrm{pg} / \mathrm{hr}$. There was no significant correlation between them.

Fig. 5 shows the changes in MBP, PRA and UPGE in the first group of rats. After the captopril infusion, MBP markedly decreased from $206 \pm 8$ to $119 \pm 7.5$ $\mathrm{mmHg}$, but PRA or UPGE did not change significantly. Subsequent addition of indomethacin resulted in marked decrease in UPGE from $915 \pm 234$ to $109 \pm 28$ $\mathrm{pg} / \mathrm{hr}$. PRA increased from $22.1 \pm 4.2$ to $34.1 \pm 7.1 \mathrm{ng} / \mathrm{ml} / \mathrm{hr}$, while MBP decreased further to $100 \pm 12 \mathrm{mmHg}$.

Fig. 6 shows the changes in MBP, PRA and UPGE in the second group of rats. The first infusion of indomethacin resulted in a marked decrease in UPGE

Fig. 3. Comparison of mean blood pressure (MBP), plasma renin activity (PRA) and urinary excretion of PGE (UPGE) in the control period between the first group (SQ FIRST, hatched bars, $n=7$ ) and the second group (IND FIRST, open bars, $n=7$ ) of renal hypertensive rats. Values are means \pm s.e.
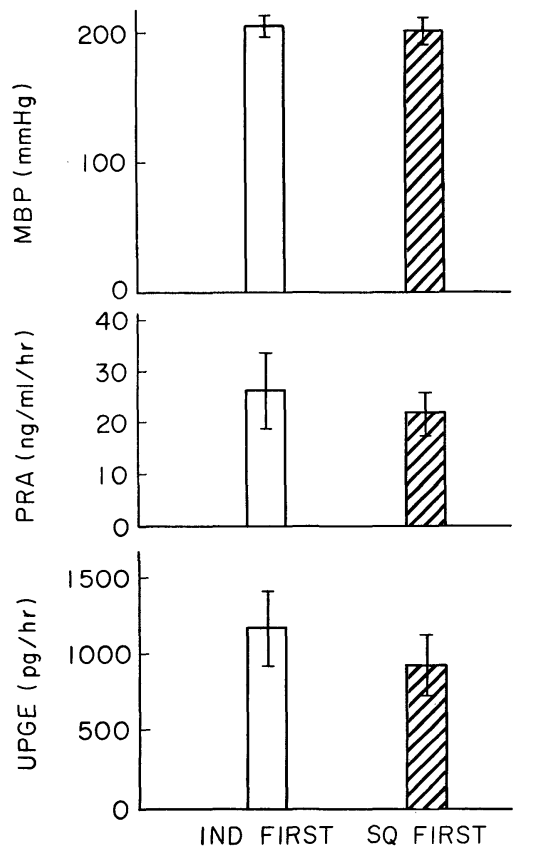


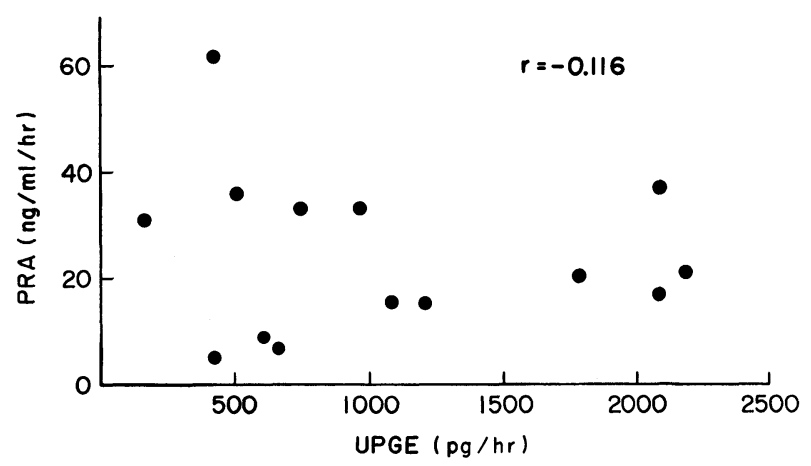

Fig. 4. Relationship between the level of plasma renin activity (PRA) and urinary excretion of PGR (UPGE) in the control period in two kidney one clip Goldblatt hypertensive rats.

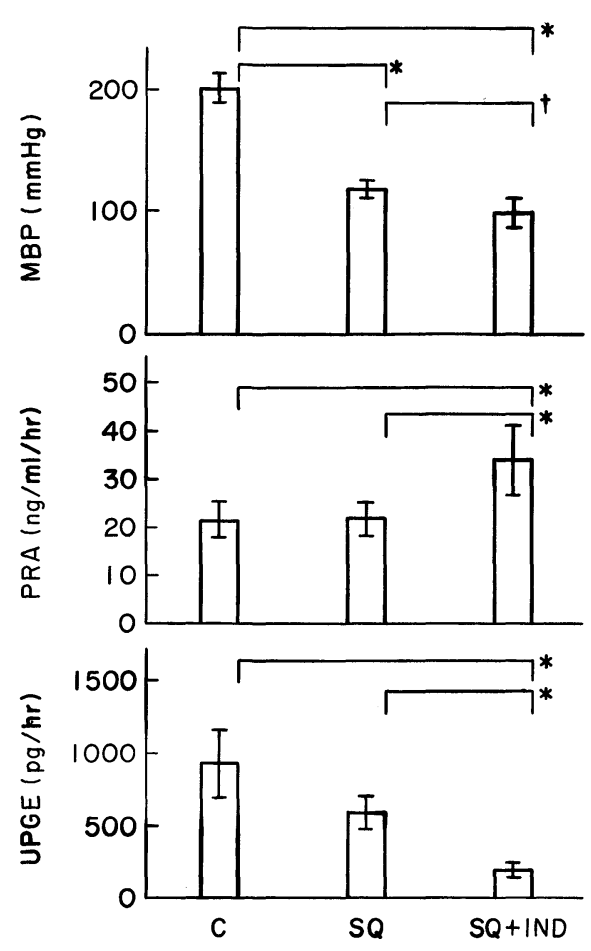

Fig. 5 .
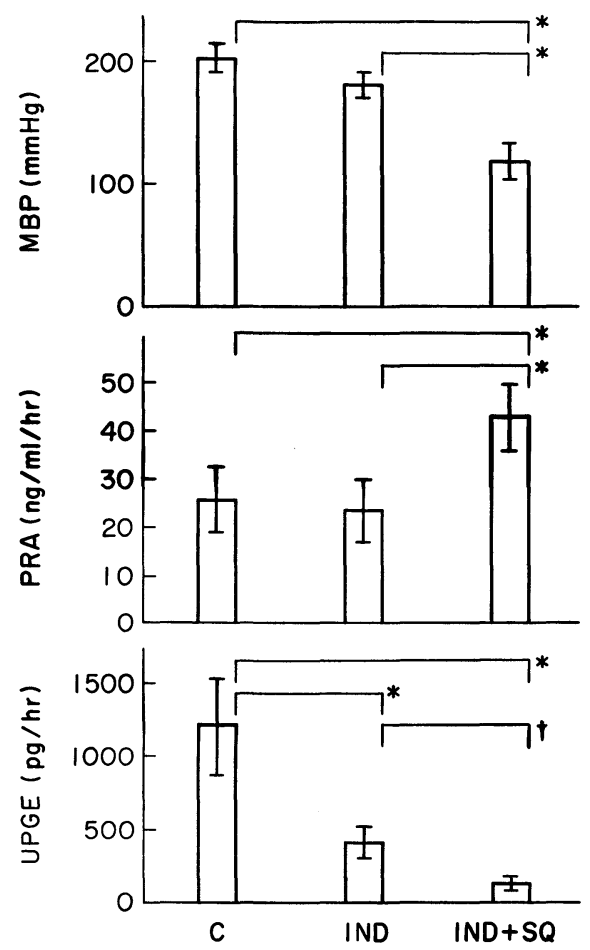

Fig. 6.

Fig. 5. Changes of mean blood pressure (MBP, top), plasma renin activity (PRA, middle) and urinary excretion of PGE (UPGE, bottom) in the control period (C), after captopril infusion (SQ) and after the addition of indomethacin (SQ+IND) in the first group of renal hypertensive rats. Values are means \pm s.e. In this figure and in Fig. 6, significant difference is given by $* p<0.01$ and $\dagger p<0.05$.

Fig. 6. Changes of mean blood pressure (MBP, top), plasma renin activity (PRA, middle) and urinary excretion of PGE (UPGE, bottom) in the control period (C), after indomethacin infusion (IND) and after the addition of captopril (IND+SQ) in the second group of renal hypertensive rats. Values are means \pm s.E. 


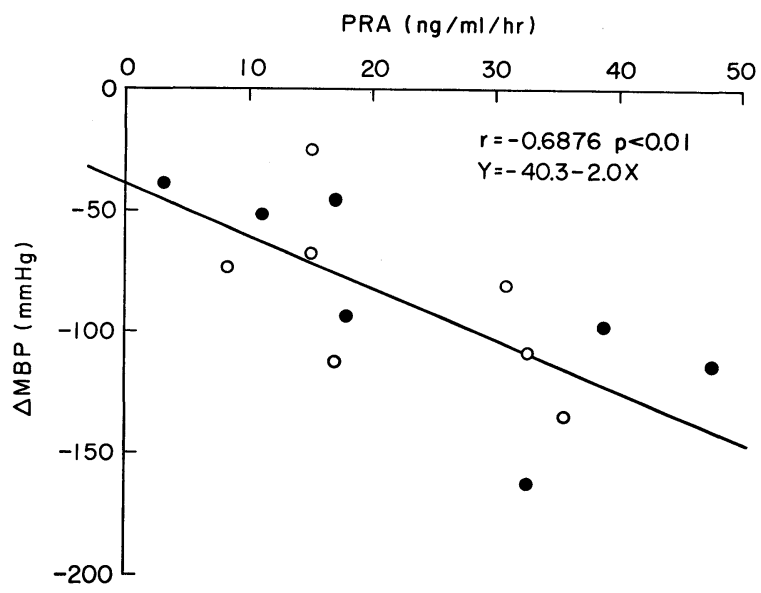

Fig. 7. The relationship between the fall in mean blood pressure $(\triangle M B P)$ produced by captopril infusion and the level of plasma renin activity (PRA) prior to the infusion of captopril in renal hypertensive rats of the first $(\bullet)$ and the second $(0)$ group $(r=-0.6876$, $p<0.01)$.

from $1219 \pm 294$ to $413 \pm 101 \mathrm{pg} / \mathrm{hr}$, but did not produce any change in MBP or PRA. The additional infusion of captopril lowered the MBP from $187 \pm 19$ to $119 \pm 15$ $\mathrm{mmHg}$ and induced significant increase in PRA from $24.1 \pm 6.1$ to $43.3 \pm 6.9 \mathrm{ng} / \mathrm{ml} /$ hr. UPGE decreased further to $96 \pm 42 \mathrm{pg} / \mathrm{hr}$.

Fig. 7 shows the correlation between the level of PRA prior to the infusion of captopril and the decrease of MBP in the rats of either group. Significant negative correlation was found between these two parameters $(r=-0.6876, p<0.01)$.

\section{Changes in $U N a$ and $U K$ excretion}

Table 1 shows UNa and UK excretion in each period in the first group of rats. UNa excretion was $95.6 \pm 23.5$, UK excretion was $63.2 \pm 11.7 \mu \mathrm{Eq} / \mathrm{hr}$ in the control period. UNa excretion did not increase after captopril infusion, but decreased significantly by the additional infusion of indomethacin from 49.0 \pm 5.4 to $22.8 \pm 3.5 \mu \mathrm{Eq} / \mathrm{hr}$. UK excretion did not change significantly in any period in the first group of rats.

Table 2 shows the data in the second group of rats. There were no significant

Table 1. Urinary sodium excretion (UNa) and urinary potassium excretion (UK) in the control period, after captopril infusion (SQ) and after the addtion of indomethacin $(S Q+I N D)$ in the first group of renal hypertensive rats

\begin{tabular}{lccl}
\hline & Control & \multicolumn{1}{c}{ SQ } & SQ+IND \\
\hline $\mathrm{UNa}(\mu \mathrm{Eq} / \mathrm{hr})$ & $95.6 \pm 23.5$ & $49.0 \pm 5.4$ & $22.8 \pm 3.5^{*}$ \\
$\mathrm{UK}(\mu \mathrm{Eq} / \mathrm{hr})$ & $63.2 \pm 11.7$ & $50.0 \pm 10.8$ & $54.9 \pm 14.7$ \\
\hline
\end{tabular}

Values are mean \pm s.E.

$* p<0.01$ significantly different from control. 
TABLE 2. Urinary sodium excretion (UNa) and urinary potassium excretion (UK) in the control period $(C)$, after indomethacin infusion (IND) and after the addition of captopril (IND+SQ) in the second group of renal hypertensive rats

\begin{tabular}{lrcc}
\hline & Control & IND & IND+SQ \\
\hline $\mathrm{UNa}(\mu \mathrm{Eq} / \mathrm{hr})$ & $138.6 \pm 55.2$ & $70.8 \pm 11.7$ & $46.3 \pm 8.3$ \\
$\mathrm{UK}(\mu \mathrm{Eq} / \mathrm{hr})$ & $74.6 \pm 18.6$ & $72.3 \pm 13.0$ & $70.1 \pm 14.8$
\end{tabular}

Values are means \pm s.E.

change in UNa or UK excretion in any period. In the control period UNa excretion was $138.6 \pm 55.2 \mu \mathrm{Eq} / \mathrm{hr}$, and $\mathrm{UK}$ excretion was $74.6 \pm 18.6 \mu \mathrm{Eq} / \mathrm{hr}$. There were no significant changes in UNa or UK excretion between the two groups of rats in the control period.

\section{Discussion}

Recently, many attempts have been made to clarify the mechanism of hypotensive action of captopril, a newly developed angiotensin converting enzyme inhibitor. The kinin accumulation as well as the inhibition of angiotensin converting enzyme by captopril is assumed to be related to the hypotensive action of this drug, but the detailed mechanism of the hypotensive action remains still to be elucidated. Indomethacin, an inhibitor of prostaglandin synthesis (Vane 1971) has been widely used as a tool to assess the physiological role of PGs. Rubin et al. (1978) have shown that indomethacin attenuates the response to bradykinin in normal rabbits, thus postulating that renal PGs may play a major role in the bradykinin induced hypotension. McGiff et al. $(1970,1972)$ have reported that PGs antagonize the vasoconstrictor effect of pressor substances and potentitate the vasodilator effect of bradykinin. These studies may lend support to the hypothesis that PGs mediated by the kinin accumulation induced by captopril may participate in the hypotensive effect of captopril. In this hypothesis, indomethacin could attenuate the hypotensive effect of captopril. In our experiments, however, indomethacin did not attenuate the hypotensive effect of captopril depsite a marked decrease in urinary excretion of PGE in two kidney one clip Goldblatt hypertensive rats. These data indicate that this hypothesis is unlikely. Our data were in accordance with the study of Murthy et al. (1978) in which indomethacin did not attenuate the hypotensive effect of captopril in normal rabbits. Antonaccio et al. (1979) also reported that indomethacin did not alter the hypotensive effect of captopril in spontaneously hypertensive rats. Our data, however, do not eliminate the possibility that the captopril-induced kinin accumulation could participate in the hypotensive effect of captopril through its direct vasodilator action, since antibody against kinin attenuates the hypotensive effect of captopril in renovascular hypertension in rats (Carretero et al. 1981).

In our experiments, captopril completely blocked the pressor response to angiotensin I, and the magnitude of the reduction of MBP was related to the PRA 
level prior to the administration of captopril. These data indicate that the hypotensive effect of captopril is mainly due to the inhibition of the conversion of angiotensin I to angiotensin II in renovascular hypertension in rats.

In the first group, MBP decreased significantly after the subsequent dose of indomethacin. It seems that this reduction of MBP was not the effect of indomethacin since administration of indomethacin alone did not decrease the MBP in the second group of rats.

Renal PGs have been shown to play an important role in renin release under basal as well as stimulated conditions (Larsson et al. 1974; Patak et al. 1975; Bailie et al. 1976). In our experiments, however, indomethacin did not decrease the basal level of PRA nor did inhibit the enhanced renin secretion by captopril despite a decrease in UPGE excretion. There are several possible reasons for the difference between our study and previous reports. First, it may come from the species difference. Secondly, since Romero et al. (1976) reported that the ability of indomethacin to decrease the basal value of PRA and to prevent its elevation by hemorrhage depends largely on the administered dose, the dose of indomethacin we used may be too small to decrease the PRA. In other words, the effective dose of indomethacin to inhibit renal PGE synthesis may differ from that of indomethacin to inhibit another PGs which participate in the renin secretion. Our data are in accordance with the study of Antonaccio at al. (1979) in which indomethacin did not inhibit the renin increase induced by captopril in spontaneously hypertensive rats. Therefore, it is unlikely that renal PGs may participate in the renin secretion after captopril administration in rats.

McCaa et al. (1978) reported that the administration of captopril resulted in natriuresis and diuresis in sodium depleted dogs. In our study, however, UNa excretion did not increase after the administration of captopril. It may be possible that this discrepancy comes from the changes of blood pressure. When the blood pressure does not decrease, blockade of the renin-angiotensin system results in natriuresis due to the reduced aldosterone secretion and renal vasodilatation. When the blood pressure falls, UNa excretion does not increase because of the increase in the proximal sodium reabsorption and the decrease in the glomerular filtration. Indeed, Miurhead et al. (1978) also reported that captopril decreased MBP but did not change UNa excretion in spontaneously hypertensive rats. In the first group of rats, UNa excretion decreased significantly after the subsequent treatment with indomethacin. It could be that this decrease in sodium excretion results from the decrease in renal PGs which have been shown to participate in the renal sodium handling.

In conclusion, our data that indomethacin did not attenuate the hypotensive effect of captopril indicate that PGs do not participate in the hypotensive action of captopril and that the hypotensive action of captopril is mainly due to the inhibition of renin-angiotensin system in two kidney one clip Goldblatt hypertensive rats. 


\section{Acknowledgment}

This work was supported by research grants (No. 348204 and No. 357302) from the Ministry of Education, Science and Culture, Japan. We acknowledge the technical assistance of Miss Sinko Goto, Miss Mitsuko Okamoto and Miss Miki Kohata.

\section{References}

1) Abe, K., Otsuka, Y., Saito, T., Chin, B.S., Aoyagi, H., Miyazaki, S., Irokawa, N., Seino, M., Miura, Y., Ono, I., Kobayashi, K., Seki, K., Sato, T. \& Yoshinaga, K. (1972) Measurement of plasma renin activity by agiotensin I radioimmunoassay: A modification of Haber's method. Jap. Circulat. J., 36, 741-749.

2) Abe, K. Yasujima, M., Chiba, S., Irokawa, N., Ito, T. \& Yoshinaga, K. (1977) Effect of furosemide on urinary excretion of prostaglandin $\mathrm{E}$ in normal volunteers and patients with essential hypertension. Prostaglandins, 14, 513-521.

3) Akien, J.W. \& Vane, J.W. (1973) Intrarenal prostaglandin release attenuates the renal vasoconstrictor activity of angiotensin. J. Pharmxcol. exp. Ther., 184, 678-687.

4) Antonaccio, M.J., Harris, D., Goldenberg, H., High, J.P. \& Rubin, B. (1979) The effect of captopril, propranolol and indomethacin on blood pressure and plasma renin activity in spontaneously hypertensive and normotensive rats. Proc. Soc. exp. Biol. Med., 162, 429-433.

5) Bailie, M.D., Crosslan, K. \& Hook, J.B. (1976) Natriuretic effect of furosemide after inhibition of prostaglandin synthesis. J. Pharmacol. exp. Ther., 199, 469-476.

6) Carretero, O.A., Miyazaki, S. \& Scicli, A.G. (1980) Role of kinins in the antihypertensive effect of converting enzyme inhibitor. Hypertension, 3, 18-22.

7) Erdös, E.G. \& Yong, H.Y.T. (1970) Kininases. In: Handbook of Experimental Pharmacology, edited by E.G. Erdös, Springer-Verlag, New-York, pp. 289-323.

8) Jaffe, B.M. \& Behrman, H.R. (1974) Prostaglandins E, A and F. In: Methods in Hormone Radioimmunoassay, edited by B.M. Jaffe \& H.R. Behrman, Academic Press, New-York, pp. 19-34.

9) Larsson, C., Weber, P. \& Anggard, E. (1974) Arachidonic acid increases and indomethacin decreases plasma renin activity in the rabbit. Europ. J. Pharmacol., 28, 391-394.

10) Muirhead, E.E., Prewitt, R.L., Brooks, B. \& Brosius, W.L. (1978) Antihypertensive action of the orally active converting enzyme inhibitor (SQ 14,225) in spontaneously hypertensive rats. Circulat. Res., 43 (Suppl. I), I-53-I-59.

11) McCaa, R.E., Hall, J.E. \& McCaa, C.S. (1978) The effect of angiotensin I-converting enzyme inhibitors on arterial blood pressure and urinary sodium excretion. Role of the renal renin-angiotensin and kallikrein-kinin system. Circulat. Res., 43 (Suppl. I), I32-I-39.

12) McGiff, J.C., Crowshaw, K., Terragno, N.A. \& Lonigro, A.J. (1970) Release of a prostaglandin-like substance into renal venous blood in response to angiotensin II. Circulat. Res., 26, 27 (Suppl. I), I-121-I-130.

13) McGiff, J.C., Terragno, N.A., Malik, K.U. \& Lonigro, A.J. (1972) Release of a prostaglandin E-like substance from canine kidney by bradykinin: comparison with eledoisin. Circulat. Res., 31, 36-43.

14) Murthy, V.S., Waldron, T.L. \& Goldberg, M.E. (1978) The mechanism of bradykin in potentiation after inhibition of angiotensin-converting enzyms by SQ 14,225 in conscious rabbits. Circulat. Res., 43, (Suppl. I), I-40-I-45.

15) Otsuka, Y., Carretero, O.A., Albertini, R. \& Binia, A. (1979) Angiotensin and sodium balance: Their role in chronic two-kidney Goldblatt hypertension. Hypertension, 1, 389-396.

16) Patak, R.V., Mookerjee, B.K., Bentzel, C.J., Hysert, P.E., Babeu, M. \& Lee, J.B. (1975) Antagonism of the effects of furosemide by indomethacin in normal and hypertensive man. Prostaglandins, 10, 649-659. 
17) Romero, J.C., Dunlap, C.L. \& Strong, C.G. (1976) The effect of indomethacin and other anti-inflammatory drugs on the renin angiotensin system. J. clin. Invest., 58, 282-288.

18) Rubin, B., Antonaccio, M.J. \& Horovitz, Z.P. (1978) Captopril (SQ 14,225) (D-3mercapto-2-methylpropanyl-L-proline): A novel orally active inhibitor of angiotensinconverting enzyme and antihypertensive agent. Fed. Proc., 21, 183-194.

19) Vane, J.R. (1971) Inhibition of prostaglandin synthesis as a mechanism of action for aspirin-like drugs. Nature (New Biology), 231, 232-235.

20) Yun, J.C.H., Kelly, G., Barter, F.C. \& Smith, H.C. (1976) Role of prostaglandins in the control of renin secretion. Fed. Proc., 35, 620. 